17. Краснов А.Е., Сагинов Ю.Л., Феоктистова Н.А. Алгебраические основы нейросетевой декомпозиции и агрегирования динамических систем // Сборник трудов V Международной конференции: III международный конкурс научных и научно-методических работ. Международная академия информатизации, Московский государственный университет технологий и управления имени К.Г. Разумовского, 2015 г., с. 23-27.

18. Веселов Г.Е. Проблема синтеза иерархических стратегий группового управления робототехническими системами // Известия ЮФУ. Технические науки, 2011 г., с. 41-49.

19. Кириллов А. Н. Метод динамической декомпозиции в моделировании систем управления со структурными изменениями // Информационно-управляющие системы, 2009 г., с. 20-24.

20. Первозванский А.А., Гайцгори В.Г. Декомпозиция, агрегирование и приближенная оптимизация. - М.: Наука, 1979. - 344 с.

21. Абгарян К.А. Расщепление сингулярно возмущенной многотемповой системы // Известия академии наук Армянской ССР, Математика, №5, 1979 г., с. 327-337.

22. Фрадков А.Л. Адаптивное управление в сложных системах: беспоисковые методы. - М.: Наука. Гл. ред. физ.-мат. лит., 1990. - 296 с.

23. Камачкин А.М., Шамберов В.Н. Метод декомпозиции в многомерных нелинейных динамических системах // Вестник воронежского государственного университета. Серия: системный анализ и информационные технологии, №1, 2012 г., с. 47-55.

24. Абгарян К.А. Асимптотическое расщепление уравнений линейной системы автоматического управления//ДАН СССР. 1966. Т. 166. № 2, с. 301-304.

25. Петров В. В. Нелинейные сервомеханизмы: монография / В. В. Петров, А. А. Гордеев. - М.: Машиностроение, 1979. - 471 с.

26. Дерусо П. Пространство состояний в теории управления (для инженеров): монография / П. Дерусо, Р. Рой, Ч. Клоуз; пер. с англ. Р. Т. Янушевского; под ред. М. В. Меерова, - М.: Наука, 1970. - 620 с.

27. Викторова В.С., Свердлик Ю.М., Степанянц А.С. Анализ надежности систем сложной структуры на многоуровневых моделях // Автоматика и телемеханика, 2010 г., с. 143-148.

28. Крон Г. Исследование систем по частям: диакоптика М.: Наука. 1972. 544c.

29. Петров А.Е. Обобщенная диакоптика для управления в системах с переменной структурой // Десятая всероссийская мультиконференция по проблемам управления МКПУ-2017, 2017, с. 207-209.

30. A. Iftar Decentralized estimation and control with overlapping input, state and output decomposition// Automatica, №29 (1993), pp. 511-516.

31. Xin-Yu OUYANG, Xue-Bo CHEN, Wei WANG Modeling and decomposition of complex dynamic interconnected systems, IFAC Proceedings Volumes, Volume 42, Issue 4, 2009, pp. 1002-1007.

32. Xue-Bo Chen, Srdjan S. Stanković Decomposition and decentralized control of systems with multi-overlapping structure, Automatica, Volume 41, Issue 10, 2005, pp. 1765-1772.

33. A.I. Zečević, D.D. Šiljak Balanced decompositions of sparse systems for multilevel parallel processing, IEEE Transactions CAS, 41 (1994), pp. 220-233.

34. Alvarado, F.L., Reitan, D.K., Bahari-Kashani, M. Sparsity in diakoptic algorithms, (1977) IEEE Transactions on Power Apparatus and Systems, 96 (5), pp. 1450-1459.

35. Felix F. WU. Solution of Large-Scale Networks by Tearing // IEEE transactions on circuits and systems, Vol. CAS-23, № 12, December 1976, pp. 706-713.

36. P. W. Aitchison Diakoptics as a general approach in engineering// Journal of Engineering Mathematics, Volume 21, 1987, issue 1, pp. 47-58.

37. Грудинин В.Н., Анисимов В.И., Алмаасали С.А. Повышение эффективности процессов моделирования нелинейных систем // Информационные технологии в проектировании и производстве, №4(152), 2013 г., с. 10-13.

38. Анисимов В.И., Тарасова О.Б., Алмаасали С.А. Организация вычислительных процессов при моделировании систем на основе методов диакоптики // Информационные технологии в проектировании и производстве, №4(152), 2013 г., с. 14-17.

\title{
Morozova O.O. \\ The mathematical models in the process of organization of the services of search and rescue ensuring flights
}

Autonomous noncommercial organization of additional education" Agency of Technological development Ulyanovsk region", leading specialist in science

doi: $10.18411 / s r-10-12-2018-19$

(Russia, Ulyanovsk)

idsp: sciencerussia-10-12-2018-19

\section{Abstract}

This article discusses the approach to the planning of the service of search and rescue support of flights on the basis of the application of a mathematical model.

Keywords: mathematical model, list of measures, emergency situation. 
This article proposes the using of mathematical models in the organization of the service of search and rescue support of flights (hereinafter - PASOP), which is based on the task of effective distribution of available forces and means in case of emergency situations.

If to accept for $S_{i}$ - the list of forces and means used by service PASOP (where $i=\overline{1, I}$ ); $N_{m}$ - the event or the emergency situation which arose in a zone of responsibility of service PASOP (where $m=\overline{1, M}$ ). The corresponding list of actions $G_{m i}(m=\overline{1, M})$ on elimination of the arisen emergency situation $\mathrm{N}_{\mathrm{m}}$ (technological, technical processes) can be represented in the form of a matrix:

Matrix of activities-rescue, search operations

\begin{tabular}{|c|c|c|c|c|c|c|}
\hline \multirow{2}{*}{$\begin{array}{c}\text { Emergency } \\
\text { situation }\end{array}$} & \multicolumn{6}{|c|}{ The forces and means of service PASOP } \\
\cline { 2 - 7 } & $\mathrm{S}_{1}$ & $\mathrm{~S}_{2}$ & $\ldots$ & $\mathrm{S}_{\mathrm{i}}$ & $\ldots$ & $\mathrm{S}_{\mathrm{I}}$ \\
\hline $\mathrm{N}_{1}$ & $\mathrm{G}_{11}$ & $\mathrm{G}_{12}$ & $\ldots$ & $\mathrm{G}_{1 \mathrm{i}}$ & $\ldots$ & $\mathrm{G}_{1 \mathrm{I}}$ \\
\hline $\mathrm{N}_{2}$ & $\mathrm{G}_{21}$ & $\mathrm{G}_{22}$ & $\ldots$ & $\mathrm{G}_{2 \mathrm{i}}$ & $\ldots$ & $\mathrm{G}_{2 \mathrm{I}}$ \\
\hline $\mathrm{N}_{3}$ & $\mathrm{G}_{31}$ & $\mathrm{G}_{32}$ & $\ldots$ & $\mathrm{G}_{3 \mathrm{i}}$ & $\ldots$ & $\mathrm{G}_{3 \mathrm{I}}$ \\
\hline$\ldots$ & $\ldots$ & $\ldots$ & $\ldots$ & $\ldots$ & $\ldots$ & $\ldots$ \\
\hline$\ldots$ & $\ldots$ & $\ldots$ & $\ldots$ & $\ldots$ & $\ldots$ & $\ldots$ \\
\hline $\mathrm{N}_{\mathrm{m}}$ & $\mathrm{G}_{\mathrm{m} 1}$ & $\mathrm{G}_{\mathrm{m} 2}$ & $\ldots$ & $\mathrm{G}_{\mathrm{mi}}$ & $\ldots$ & $\mathrm{G}_{\mathrm{mI}}$ \\
\hline$\ldots$ & $\ldots$ & $\ldots$ & $\ldots$ & $\ldots$ & $\ldots$ & $\ldots$ \\
\hline$\ldots$ & $\ldots$ & $\ldots$ & $\ldots$ & $\ldots$ & $\ldots$ & $\ldots$ \\
\hline $\mathrm{N}_{\mathrm{M}}$ & $\mathrm{G}_{\mathrm{M} 1}$ & $\mathrm{G}_{\mathrm{M} 2}$ & $\ldots$ & $\mathrm{G}_{\mathrm{Mi}}$ & $\ldots$ & $\mathrm{G}_{\mathrm{MI}}$ \\
\hline
\end{tabular}

The task is to determine the list of $\mathrm{G}_{\mathrm{mi}}$ activities that include $S_{i}$ forces and means, when the $N_{m}$ event occurs, which will be most effective with minimal execution time:

$$
\sum_{\mathrm{m}=1}^{\mathrm{M}} \sum_{\mathrm{i}=1}^{\mathrm{I}} \mathrm{T}_{\mathrm{mi}} \cdot \mathrm{G}_{\mathrm{mi}} \rightarrow \min
$$

All processes will be considered only those that will fit the following condition:

$$
\left\{\begin{array}{l}
\mathrm{P}\left(\mathrm{T}_{\mathrm{mi}}>\mathrm{t}_{\mathrm{mi}}\right) \rightarrow \max \\
\mathrm{T}_{\mathrm{mi}} \leq \mathrm{t}_{\mathrm{mi}} \\
\mathrm{t}_{\mathrm{mi}} \geq 0 \\
\mathrm{~T}_{\mathrm{mi}} \geq 0
\end{array}\right.
$$

where $t_{\mathrm{mi}}$ - the specified (standard set) time of execution of technological operations, works of PASOP services;

$\mathrm{T}_{\mathrm{mi}}$ - the time required to perform $\mathrm{Z}_{\mathrm{mi}}$ operations to prevent or mitigate the aftermath of the $\mathrm{N}_{\mathrm{m}}$ event;

$\mathrm{P}\left(\mathrm{T}_{\mathrm{mi}}>\mathrm{t}_{\mathrm{mi}}\right)$ - the probability that the time of the operation will not exceed the standard set time.

In this case, it is assumed that the implementation of rescue, search operation includes all stages of work using all necessary forces and means.

When using such mathematical models, it is advisable to develop an assessment of the quality of rescue and search operations, the adequacy of using of forces and means at a set time. This will allow to form an effective list of activities with a description of the necessary 
forces and means of PASOP services, to determine their sequence in the event of various emergency situations.

1. Morozova, O. O. Effective planning of work of services of search and rescue ensuring flights // Modernization of economic systems: a look into the future (MESLF): collection of scientific works / under the editorship of P. A. Neverov, A. B. Amanzholova - Prague : Vedecko vydavatelske centrum "Sociosfera-CZ”, 2016. P. 243-245.

2. Morozova, O. O. Optimization of management decisions in the safety management system of airlines on the basis of the mathematical model of total costs // scientific Bulletin of MSTU GA. 2013. № 197 (11). - P.145147. 